BERKALA FISIKA INDONESIA
$2085-0409$ (Print) $\mid 2550-0465$ (online)

\title{
The problem of physics learning: The effort to increase the interest and learning result of Newton laws
}

\author{
Tomy Suganda ${ }^{1 *}$, Endang Purwaningsih ${ }^{2}$, Parno $^{3}$ \\ 1,2,3 Physics Education Department, Universitas Negeri Malang, Indonesia \\ Email: tomysuganda25@gmail.com* \\ * Penulis korespondensi
}

\begin{tabular}{l}
\hline Informasi artikel \\
\hline Sejarah artikel: \\
Dikirim \\
Revisi \\
Diterima \\
\hline
\end{tabular}

\section{Kata kunci:}

Alat Peraga

Hukum Newton

Pembelajaran Fisika

\begin{abstract}
ABSTRAK
Penelitian ini bertujuan untuk mengidentifikasi masalah dan solusi pembelajaran fisika pada konsep hukum gerak newton. Peneliti menggunakan penelitian deskriptif kualitatif dengan sampel siswa dan guru fisika di SMA Islam atau Madrasah Aliyah di Malang. Pengumpulan data dilakukan melalui wawancara dan observasi selama dua kali pertemuan. Pertemuan pertama adalah sesi wawancara dengan guru untuk mengidentifikasi masalah dalam pembelajaran fisika. Pertemuan kedua adalah observasi mahasiswa untuk penyelidikan lebih lanjut berdasarkan temuan dari hasil wawancara. Penelitian ini dirancang untuk memecahkan masalah pembelajaran fisika pada konsep hukum gerak newton. Hasil penelitian menunjukkan bahwa pembelajaran di kelas masih menggunakan pendekatan yang berpusat pada guru, sehingga menghasilkan respon interaktif dan hasil belajar yang kurang baik. Selain itu, fasilitas sekolah kurang mendukung seperti peralatan belajar dan laboratorium. Oleh karena itu, alat peraga dapat meningkatkan kualitas dan kuantitas siswa pada pembelajaran konsep hukum gerak newton.
\end{abstract}

This is an open access article under the CC-BY-SA license

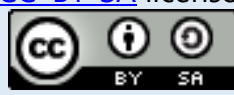

\section{ABSTRACT}

The problem of physics learning: The effort to increase the interest and learning result of Newton laws. This study aimed to identify the problems and solutions of physics learning on the concept of newton's law of motion. The researcher used a qualitative descriptive study with a sample of students and physics teachers at Islamic Senior High School or Madrasah Aliyah in Malang. The data was collected through interviews and observations during two meetings. The first meeting was an interview section with the teachers to identify the problems in physics learning. The second meeting was the student observations for further investigation based on the findings from the interview data. This present study was designed for solving physics learning problems on the concept of newton's law of motion. The result showed that classroom learning still utilises a teacher-centred approach, resulting in poor interactive responses and learning outcomes. Besides, The school does not support enough facilities, such as learning equipment and laboratories. Therefore, teaching aids can improve the students' quality and quantity on learning the concept of newton's law of motion.

\section{How to Cite:}

Suganda, T., Purwaningsih, E., \& Parno. (2021). The problem of physics learning: The effort to increase the interest and learning result of Newton laws. Berkala Fisika Indonesia: Jurnal Ilmiah Fisika, Pembelajaran dan Aplikasinya, 12(1), 25-32. 


\section{Introduction}

Learning activities based on the 2013 curriculum provide broad opportunities for students to master the competencies needed for their present and future lives. Learning is an activity that is not just memorising and storing knowledge, but rather how students' knowledge can be meaningful through thinking skills (Sanjaya, 2006). The learning process is essential because this process determines whether the achievements obtained from one's learning are good or not. The role of the teacher in arranging student learning activities has a significant impact on student learning outcomes. The teacher's role is mainly in learning physics activities, including identifying problems, formulating hypotheses, designing experiments, making observations, recording experimental data, testing hypotheses, and making conclusions (Sutarto et al., 2018).

Physics is a fundamental branch of natural science for students where they are expected to understand the natural phenomena around them. Physics is at the heart of developing information and communication technology that has changed human life (Abdurrahman et al., 2011). Physics is presented with the hope that students can master concepts and apply scientific steps in solving the problems they face (Sambada, 2012). But in fact, physics is an unattractive and unattractive subject, both at school and university (Abdurrahman et al., 2011).

Interest is an internal factor that affects the learning process. Interest will arise when individuals are interested in something because it follows their needs or feels that something to be learned is felt meaningful so that students intend to learn it (Yunita et al., 2015). According to Sembiring \& Mukhtar (2013), students with a high interest in learning have curiosity about finding or solving problems, so they are not easily influenced by the thought that exact lessons are difficult lessons. On the other hand, students with low interest in learning tend to withdraw from associations, are closed, and feel they cannot master learning material. If this is allowed and not handled, it will make students have difficulty understanding the lesson. A learning approach that does not attract students' attention and interest will undoubtedly impact student learning outcomes that are always under the KKM (Magfirah et al., 2018).

Learning outcomes are something students get through learning activities that involve interactions between learning experiences in a basic competency in knowledge, skills, and attitudes (Kunandar, 2011). Learning results are essentially changes in behaviour due to interactions with the environment (Asta et al., 2015). Learning results are influenced by two factors, namely internal factors such as physical and psychological and external factors such as family and school (Slameto, 2015). The benchmark for learning physics's success can be seen from the learning results (Hatika, 2016; Rerung et al., 2017).

Student interest and learning results are among the problems in learning physics, often discussed as a research problem. Several studies related to physics learning problems have been carried out, as was done by Samudra et al. (2014), which found that physics learning problems include the following: 
a). students think that physics is difficult to understand because there is much memorisation and contains many mathematic elements. b). students expect simple and contextual physics lessons c). students do not like teachers who pay less attention to students d). students are interested and motivated to learn physics, but on the other hand, they also feel not gifted. The findings of Yusuf $\&$ Subaer (2013) state that students' quality and learning process is determined by many factors, one of which is laboratory facilities. Besides, problems can also arise when physics teachers lack creativity in designing practicum designs and developing equipment (Wattimena et al., 2014). There has never been any research that examines a physics problem based on material by providing learning solutions based on existing issues. Therefore, in this study, props are used as a solution to learning problems.

The physics material that needs to be studied in Newton's law. Newton's law discusses the relationship between internal and external forces acting on an object (Giancoli, 2015). Newton's law is a bridge to study other material in physics learning. Suppose students do not understand Newton's law material. In that case, this will make it difficult for them to understand different materials (Sari et al., 2018). Newton's law has unique characteristics where this material is very easy to express but often causes errors that arise due to students' poor understanding. Newton's law material has an abstract concept, namely the concept of force and motion, which causes students to understand it (Alias \& Ibrahim, 2015). Based on the above problems, the researcher wanted to see the extent of the physics learning problems with Newton's law material, followed by providing solutions to the issues.

\section{Method}

The type of this research is a descriptive study using interview, observation, and literature study methods. The research subjects were teachers and students involved in learning physics subject matter Newton's law in Madrasah Aliyah Malang city. The research was conducted in 2 meetings where; the first meeting was used to find problems by interviewing physics teachers, while the second meeting was an observation to focus on the problem's findings. The final result of the research is a solution to learning physics subject matter Newton's law. Data collection was carried out through interviews aimed at identifying obstacles in learning physics. Observations are used to strengthen the results of the interview. Meanwhile, the literature study is used as a reference for material related to research.

\section{Results and Discussion}

Newton's law learning applied in this school is still teacher-centred, namely learning by using the discovery learning model. Appreciation is given to students by paying attention to examples of the application of Newton's law in everyday life in student-owned module books. The teacher divides the students into several small groups to work on questions in the worksheets containing analysis questions about Newton's law. The teacher guides students in answering the questions on the LKS. The results of the students' answers are then presented in groups in front of the class. The lesson is closed with an 
explanation of the teacher's conclusions and assignments for the next meeting. Two elements that are very important in a teaching and learning process are teaching methods and learning aids (Sudarwanto $\&$ Hadi, 2014). When learning in class, the teacher always plays an essential role in learning. Students are not challenged to learn independently (student-centred). The current learning strategy prioritises several things, including student activities, laboratory activities, field experiences, case studies, problemsolving, discussions, and simulations (Wibowo \& Suhandi, 2013). Several published studies have revealed that a student-centred approach is more effective in increasing student interest and mastery of concepts (Saregar, 2016).
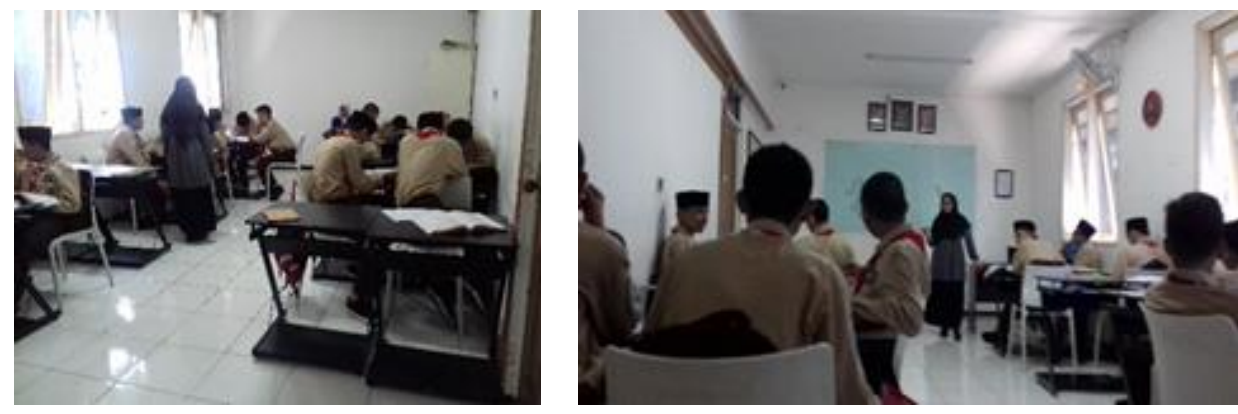

Figure 1. Learning process on Newton's law material

There are still many students whose score is below the KKM, more than half the number of students, as shown in Figure 2.

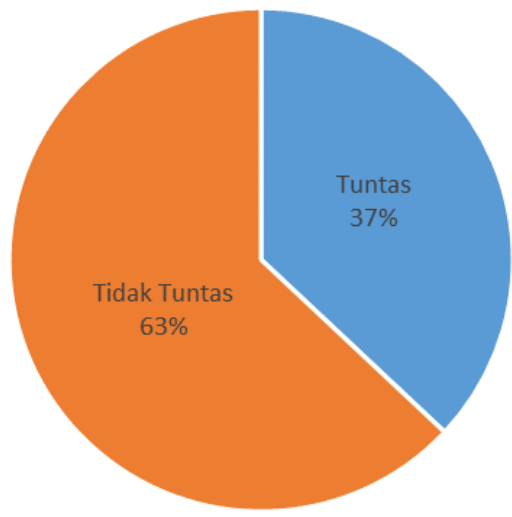

Figure 2. Percentage of student completeness in learning Newton law

The findings related to learning at school include students who rarely practice the material being studied. This is due to incomplete laboratory equipment and teachers who do not understand how to design and organise practicum schools. From the interview, the following information was obtained:

Researcher : Have students ever studied physics practicum directly in the laboratory?

Teacher : Never. For other lessons, I think they have. Besides, the laboratory equipment that we have is still lacking, and it does not allow students to study optimally.

Researcher : Do you understand the use of laboratory equipment for learning physics?

Teacher : I understand some practicum tools, but not all materials, only certain materials such as static fluids.

Researcher : Have you ever attended a seminar/training related to the use of laboratories/teaching aids?

Teacher : Never. 
Teachers who are not competent in using physics teaching materials, students who are not active in class, and lack laboratory equipment have low academic achievement and student interest (Aina, 2013). This is evident from most student learning results on newton law material that do not meet the KKM.
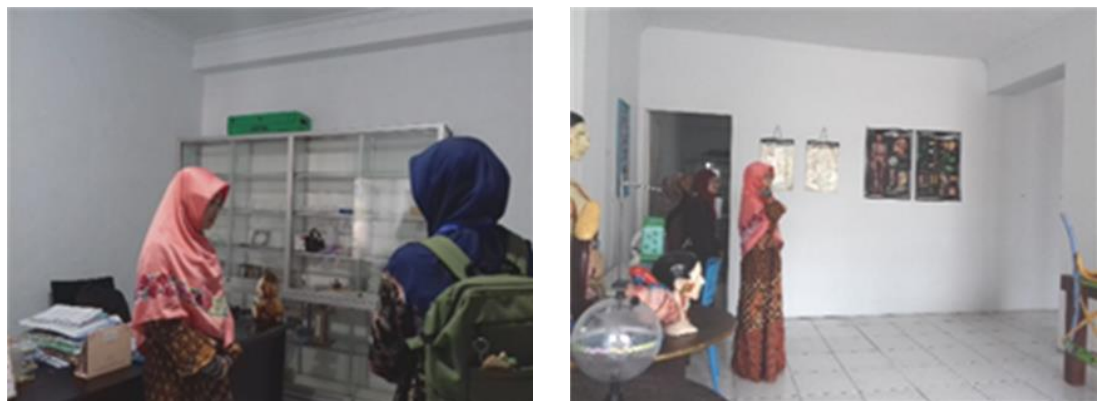

Figure 3. Laboratory conditions

Student response is still considered low. This is based on the results of interviews with the teacher, which is as follows:

Researcher : How did students give a response during the learning process?

Teacher : In certain classes, they are enthusiastic, but they don't listen to what the teacher explains and choose to joke around. Some also feel sleepy during lessons, which then makes learning ineffective.

Based on the results of interviews supported by observation sheets, it can be seen that student activities are classified based on the three observed aspects, where the results obtained are not good in the category of cooperation and expressing opinions, while in the category of responsibility in doing assignments get good results. The results of the observations showed that the student's responsibility for the assignment given is still high. Therefore, the teacher can play a role in developing a classroom atmosphere to become more enthusiastic, collaborative, and dare express their opinions. This, of course, can have an impact on student learning results in newton law material. Collaborative learning in physics classes is usually done in group activities where students conduct experiments or carry out investigative tasks. The researchers observed that with the lack of physics laboratory equipment in most public high schools to support classroom activities and demonstration of physics concepts, it is a challenge for physics teachers to provide their equipment from materials they can use to teach (Malonz \& Fajardo, 2017).

Learning media is a scholarly communication medium to improve the quality of education, both in quality and quantity. Teaching aids as a learning medium positively impacts learning activities (Hutauruk \& Simbolon, 2018). In school, the teacher has prepared to learn media through a computerised physics simulation application. However, it is not displayed through the focus due to the limited amount of focus. The following are the results of the interviews obtained by the researcher: 
Researcher : What media do you use to convey physics material?

Teacher : In certain materials, simulation assistance is sometimes given in the form of a Phet application. However, this was constrained by an absence of focus in the class, so that students only saw the explanation given through one laptop

The consideration for teachers in education lies in the mindset and perspective of students. Teachers must enter into the world of children to recognise their thought patterns and views so that children can be helped to develop better (As'ari, 2017). Such conditions should challenge teachers and education practitioners, especially in physics education, to create creative ideas to support physics learning problems in schools.

Newton's law props can be a solution to problems that exist in school. Learning using teaching aids can help overcome student learning difficulties in abstract physics concepts (Oladejo et al., 2011). Rochaeni et al. (2015) developed one of them where Newton's law props received a positive response from students. The teaching aids are chosen because they can be made following the material's concept to be taught using existing materials in the surrounding environment without spending much money. Operation of simple props does not require special skills so that their use can be more effective (Saputri $\&$ Dewi, 2014). The application of teaching aids in learning can increase student interest and learning results (Tang \& Intai, 2018). Based on the results of interviews at school, the teacher has never used teaching aids to explain Newton's law material:

Researcher : Have you ever used teaching aids during learning?

Teacher : Never. Only when there is an opportunity that suits using the existing simulation is that the learning support equipment in this school is still inadequate because this school is still newly established.

A teaching aid used in learning should meet several requirements and criteria. According to Sundayana (2014), several props requirements include a). Durable; b). The shape and colour are attractive; c). Simple and easy to operate; d). The size is practical; e). Can present concepts in actual form, pictures, or diagrams; f). Can clarify concepts and not vice versa; g). Become the basis for the growth of abstract thinking concepts for students, and g). They were making students learn to be active and independent.

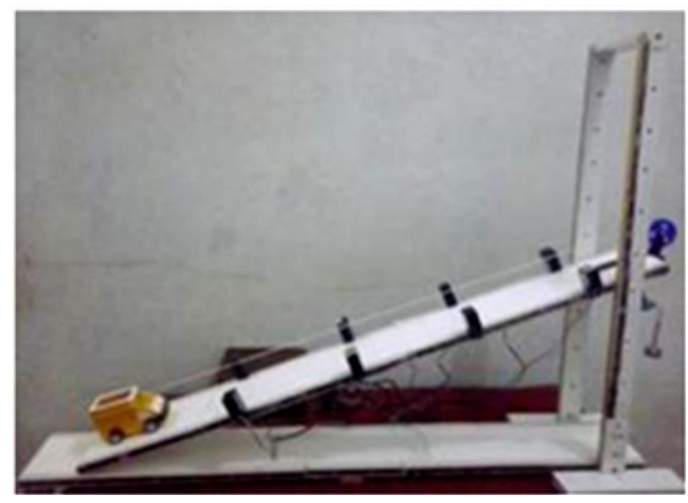

Figure 4. Examples of Newton's Law teaching aids that have been developed Rochaeni et al. (2015) 


\section{Conclusion}

Based on the research results, Newton's law material learning in Malang City schools is still teacher-centred. Learning outcomes and student responses are still low, and school facilities' support in learning equipment and laboratories is not optimal. In this case, the researcher suggests using props to help solve the problem. This suggestion is proposed considering that teaching aids can challenge teachers to innovate, increasing student interest and learning outcomes. The hope is that there will be an increase in the quality of learning physics in schools for the better. Future research should focus more on developing teaching aids as learning media to increase students' interest and learning outcomes in physics.

\section{References}

Abdurrahman, Liliasari, Rusli, A., \& Waldrip, B. (2011). Implementasi pembelajaran berbasis multi representasi untuk peningkatan penguasaan konsep fisika kuantum pendidikan. Jurnal Cakrawala, 1(1), 30-45.

Alias, S. N. B., \& Ibrahim, F. B. (2015). Problem solving strategy in balanced forces. International Journal of Business and Social Science, 6(8), 94-98.

As'ari, A. R. (2017). Tantangan pengembangan profesionalisme guru dalam rangka membelajarkan matematika di abad ke-21 dan membangun karakter peserta didik. In Tantangan Pengembangan Profesionalisme Guru dalam Rangka Membelajarkan Matematika di Abad Ke-21 dan Membangun Karakter Peserta Didik, 43-56.

Asta, K. R., Agung, A. A. G., \& Widiana, I. W. (2015). Pengaruh pendekatan saintifik dan kemampuan berpikir kritis terhadap hasil belajar IPA. Mimbar PGSD Undiksha, 3(1), 1-10.

Giancoli, D. C. (2015). Physics Principles with Applications, Global Edition. England: Pearson Education Limited.

Hatika, R. G. (2016). Peningkatan hasil belajar fisika dengan menerapkan model pembelajaran advance organizer berbantu animasi komputer. Jurnal Pendidikan Fisika Indonesia, 12(2), 13-17.

Hutauruk, P., \& Simbolon, R. (2018). Meningkatkan hasil belajar siswa dengan menggunakan alat peraga pada mata pelajaran IPA kelas IV SDN nomor 14 Simbolon Purba. School Education Journal PGSD FIP Unimed, 8(2), 121129.

Kunandar. (2011). Guru profesional: Implementasi kurikulum tingkat satuan pendidikan (KTSP) dan sukses dalam sertifikasi guru. Jakarta: Rajawali.

Magfirah, F., Tawil, M., \& Nurlina, N. (2018). Penerapan Pendekatan Keterampilan Dasar Proses Sains terhadap Hasil Belajar Fisika Peserta Didik Kelas X SMA Negeri 14 Gowa. Jurnal Pendidikan Fisika, 6(1), 21-32.

Malonz, C. R., \& Fajardo, M. T. M. (2017). Design and evaluation of demonstration tools for newton's law of motion. American Journal of Educational Research, 5(2), 155-160.

Oladejo, M. A., Ojebisi, A. O., Olosunde, G. R., \& Isola, O. M. (2011). Instructional materials and students' academic achievement in physics: Some policy implications. European Journal of Humanities and Social Sciences, 2(1), 112-126.

Rerung, N., Sinon, I. L. S., \& Widyaningsih, S. W. (2017). Penerapan model pembelajaran problem based learning (pbl) untuk meningkatkan hasil belajar peserta didik SMA pada materi usaha dan energi. Jurnal Ilmiah Pendidikan Fisika Al-BiRuNi, 6(1), 47-55.

Sambada, D. (2012). Peranan kreativitas siswa terhadap kemampuan memecahkan masalah fisika dalam pembelajaran kontekstual. Jurnal Penelitian Fisika dan Aplikasinya (JPFA), 2(2), 37-47.

Samudra, G. B., Suastra, I. W., \& Ketut Suma, M. (2014). Permasalahan-permasalahan yang dihadapi siswa SMA di kota Singaraja dalam mempelajari fisika. Jurnal Pendidikan dan Pembelajaran IPA Indonesia, 4(1), 1-7.

Sanjaya, W. (2006). Pembelajaran dalam Implementasi Kurikulum Berbasis Kompetensi. Yogyakarta: Kencana.

Saputri, V. A. C., \& Dewi, N. R. (2014). Pengembangan alat peraga sederhana eye lens tema mata kelas VIII untuk menumbuhkan keterampilan peserta didik. Jurnal Pendidikan IPA Indonesia, 3(2), 109-115.

Saregar, A. (2016). Pembelajaran Pengantar Fisika Kuantum dengan Memanfaatkan Media PhET Simulation dan LKM Melalui Pendekatan Saintifik: Dampak pada Minat dan Penguasaan Konsep Mahasiswa. Jurnal Ilmiah Pendidikan Fisika Al-BiRuNi, 5(1), 53-60. 
Sari, A. L. R., Parno, P., \& Taufiq, A. (2018). Pemahaman konsep dan kesulitan siswa SMA pada materi hukum Newton. Jurnal Pendidikan: Teori, Penelitian, \& Pengembangan, 3(10), 1323-1330.

Sembiring, R. B., \& Mukhtar. (2013). Strategi pembelajaran dan minat belajar terhadap hasil belajar matematika. Jurnal Teknologi Pendidikan, 6(2), 214-229.

Slameto. (2015). Belajar dan faktor-faktor yang mempengaruhi. Jakarta: Rineka Cipta.

Sudarwanto, S., \& Hadi, I. (2014). Pengembangan alat peraga pembelajaran matematika sekolah dasar untuk meningkatkan kemampuan berpikir matematis siswa. Sarwahita, 11(1), 32-37.

Sundayana, R. (2014). Statistika penelitian pendidikan. Bandung: Alfabeta.

Sutarto, S., Indrawati, I., Prihatin, J., \& Dwi, P. A. (2018). Geometrical optics process image-based worksheets for enhancing students' higher-order thinking skills and self-regulated learning. Jurnal Pendidikan IPA Indonesia, 7(4), 376-382.

Tang, D. K. H., \& Intai, R. (2018). Effectiveness of audio-visual aids in teaching lower secondary science in a rural secondary school. Asia Pacific Journal of Educators and Education, 32, 91-106.

Wattimena, H. S., Suhandi, A., \& Setiawan, A. (2014). Pengembangan perangkat perkuliahan eksperimen fisika untuk meningkatkan kreativitas mahasiswa calon guru dalam mendesain kegiatan praktikum fisika di SMA. Jurnal Pendidikan Fisika Indonesia, 10(2), 128-139.

Wibowo, F. C., \& Suhandi, A. (2013). Penerapan model science creative learning (SCL) fisika berbasis proyek untuk meningkatkan hasil belajar kognitif dan keterampilan berpikir kreatif. Jurnal Pendidikan IPA Indonesia, 2(1), $67-75$.

Yunita, R., Lestari, R., \& Brahmana, E. M. (2015). Minat belajar siswa kelas VIII terhadap mata pelajaran IPA di Mts. Pp. Hasanatul Barokah Tambusai Timur tahun pembelajaran 2014/2015 (Doctoral dissertation, Universitas Pasir Pengaraian).

Yusuf, I., \& Subaer. (2013). Pengembangan perangkat pembelajaran fisika berbasis media laboratorium virtual pada materi dualisme gelombang partikel di SMA Tut Wuri Handayani Makassar. Jurnal Pendidikan IPA Indonesia, 2(2), 189-194. 